\title{
The politics and aesthetics of commemoration: national days in southern Africa
}

\author{
Heike Becker and Carola Lentz
}

\begin{abstract}
:
The contributions to the special section in this issue study recent independence celebrations and other national days in South Africa, Namibia, Zimbabwe, Madagascar and the Democratic Republic of Congo. They explore the role of national days in state-making and nation-building, and examine the performativity of nationalism and the role of performances in national festivities. Placing the case studies in a broader, comparative perspective, the introduction first discusses the role of the state in national celebrations, highlighting three themes: firstly, the political power-play and contested politics of memory involved in the creation of a country's festive calendar; secondly, the relationship between state control of national days and civic or popular participation or contestation; and thirdly, the complex relationship between regional and ethnic loyalties and national identifications. It then turns to the role of performance and aesthetics in the making of nations in general, and in national celebrations in particular. Finally, we look at the different formats and meanings of national days in the region and address the question whether there is anything specific about national days in southern Africa as compared to other parts of the continent or national celebrations world-wide.
\end{abstract}

In 2010, seventeen African states celebrated their fiftieth independence anniversaries, commemorating the date on which they had become independent from their former colonial masters. Most of them did so with much pomp and pageantry, but also amidst critical reflections of disappointed hopes and future challenges. Two southern African countries, Zimbabwe and Namibia, commemorated thirty and twenty years of independence respectively. Others were still awaiting symbolically charged 'round birthdays', and merely marked their usual annual national days. In any case, Independence Day is a well-established and often the most prominent national day in Africa (as it is in many nation-states around the world). Sometimes it is (temporarily) eclipsed by other national celebrations that commemorate the coming to power of a specific regime, or it is complemented by national days that mark additional important moments in the nation's history, such as in the case of South Africa. Furthermore, Independence Day itself has often become laden with numerous meanings, thus representing not only the nation-state's 'birthday', but also, for example, the more recent turn to democracy. ${ }^{1}$

The jubilees, commemorating the 'birth' of new nation-states twenty, thirty or fifty years ago, carried a particularly strong symbolic power. Even in countries where the government was

\footnotetext{
${ }^{1}$ Parts of this introduction draw on an article by Carola Lentz (2013a, 2013b) published in the journal Nations and Nationalism; we thank the publisher for granting us permission to reuse this material.
} 
reluctant to engage in large-scale celebrations, or where the general public voiced concerns that there was actually 'nothing to celebrate', all jubilee candidates did eventually organise some form of official commemoration. Ultimately, no government would completely ignore the historical date, not least because it did not want to be outdone by other African states to whose celebrations it had been invited. Similarly, even citizens who strongly criticized their government for spending far too much on the festivities and for inviting the political elite for wining-and-dining events instead of providing basic amenities for the broader population, would not have suggested ignoring the symbolic date altogether (see Lentz and Kornes 2011 for an overview).

The 2010 celebrations presented arresting proof of the continued importance of the 'nation'. It continues to be the 'imagined community' (Anderson 1983) to which African governments regard themselves to be accountable, or at least should regard themselves to be accountable, as protest movements and the critical media have insisted in several countries. Arguably, it has been and continues to be the most important collective invoked when the political past, present and future are debated, as happened prominently during the recent commemorations of independence. These celebrations, and more generally national days, were condensed moments of nation-building, but also of state-making. They invited audiences and participants to remember, re-enact and reredefine national history, as well as to take stock of and reflect on the country's future. Since the major festive activities, like addresses to the nation, parades, or wreath-laying ceremonies, were organised by the incumbent governments, a large part of the celebrations, unsurprisingly, not only staged the state and its symbols, but also aimed at legitimising the current regime and its accomplishments. In the interstices of the official ceremonies, however, they also provided space for often intense critiques of the various governments' achievements or failures and for the articulation of new demands, which thus vied for public recognition. Furthermore, the very organisation of the official ceremonies was often contested and gave rise to passionate discussions about, for instance, ways to represent the nation's various regions and religious or ethnic traditions, which national 'heroes' to honour or pass over in silence, on whom to bestow national honours, or how to avoid a purely elitist programme. More generally, the celebrations became forums of debate about what should constitute the norms and values that make up national identity and what the future course of the country and its government should be.

At the same time, the national days presented occasions for hosting large and small popular festivals. Some popular events were organised by the official planning committees, who wished to avoid the embarrassment of empty grandstands; others were efforts by non-state initiatives such as cultural centres or neighbourhood groups. In any case, the celebrations ostensibly had the potential to instil a sense of community and to become festivities of the nation as a whole, not just of the incumbent governments.

The contributions to this special section of Anthropology Southern Africa study recent independence celebrations and other national days in southern (and central) Africa, namely in South Africa, Namibia, Zimbabwe, Madagascar and the Democratic Republic of Congo. ${ }^{2}$ They

\footnotetext{
2 All five contributions were first presented during the conference 'Celebrating the nation, debating the nation: independence jubilees, national days and the politics of commemoration in Africa', organised by Carola Lentz and Anne Brandstetter (Department of Anthropology and African Studies, Mainz University). The conference took place at the Research Centre Point Sud in Bamako, Mali, 911 January 2012 (for a report on the programme and discussions during this conference, see <http://www.pointsud.org/images/stories/pdf-2012/Programme Point Sud 2011-2012 Celebrating the Nation Debating the
} 
explore the role of national days in state-making and nation-building and investigate contested images of nationhood that national celebrations convey. Furthermore, they discuss the performativity of nationalism and the role of performances in national festivities, and, finally, the controversial politics and practices of commemoration. National symbols, as Michael Geisler (2005: 31) has pointed out, contain not only the 'victorious' versions of national history and images of the nation, but also preserve "fossilized debates, discourses, and contestations that have crystallized around them over decades". This certainly holds true for national days; during the celebrations discussed in this special section, some of the basic convictions, images and conflicts associated with nationhood and the nation-state became explicit and accessible for study. The festivals thus constituted privileged opportunities for research into the intricate connections between state-making and nation-building, and into the policies and predicaments of 'performing the nation' (Askew 2002; Fox and Miller-Idriss 2008). The articles in this special section approach the challenges presented by national-day commemorations and celebrations in contemporary southern Africa in conceptually and methodologically diverse ways. Yet they all address the intricate connections between nation-building, state-making, and performance, and explore both the integrative and stabilising function of nation-state rituals, as well as their inherent moments of contradiction, conflict and negotiation.

In the remainder of this introduction, we wish to place the case studies in a broader, comparative perspective. We will first discuss the role of the state in national celebrations and nation-building, highlighting three major themes which research on the history of national days around the globe has brought to the forefront: firstly, the political power-play and contested politics of memory involved in the very introduction (and modification) of a country's festive calendar; secondly, the relationship between state initiative and control of national days on the one hand, and civic or popular contributions to and participation in these festivals on the other; and thirdly, the contested relationship between regional and ethnic or other group loyalties and national identifications. We then turn to the role of performance and aesthetics in the making of nations in general, and in national celebrations in particular. Finally, we will take a comparative look at the different formats and meanings of national days in the region that the case studies of this special section analyse, and also address the question whether there is anything specific about national days in southern Africa as compared to other parts of the continent or national celebrations world-wide.

\section{Nation-building and state-making: the politics of national days in comparative perspective}

Nation-building is inextricably intertwined with state-making. "The reproduction of the nationstate rests not on the existence of individuals who identify with the nation," as Srirupa Roy (2007:14) has argued in her study of Indian nationalism, "but rather on their ability to identify the state as the nation's authoritative representative". This double process of state-making and nation-building entails, among others, the creation of a corps of national bureaucrats and institutions, the construction of a material infrastructure that supports nationwide communication, the establishment of schools and the spread of education (Anderson 1983,

Nation.pdf>; for a selection of revised conference papers and an overview article, see Nations and Nationalism 19 [2], 2013). Heike Becker participated in the Bamako conference and has brought to this special section her expertise of the aesthetics and politics of belonging, difference and citizenship in southern Africa. The editors of this special section wish to thank the German Research Foundation for funding the conference and Point Sud director, Mamadou Diawara, as well as the Research Centre's staff for creating an inspiring environment that allowed for intensive discussions. Thanks are due also to all presenters and participants of the conference who contributed to lively debates on national celebrations in Africa and beyond.

\section{http://repository.uwc.ac.za}


Gellner 1983). At the same time, it involves a symbolic dimension, namely, the usually state-led creation of cultural emblems, symbols and rituals, as well as the (re)writing of 'national' history. This cultural construction of the nation-state aims at integrating a heterogeneous population into a people that believes it shares, if not the same origins and cultural traditions, then a history of struggle and suffering, and a future destiny - or at the very least, that it agrees upon the importance of debating what common national values should be (Gillis 1994, Geisler 2005).

In these processes of creating 'national imaginaries' (Askew 2002), annually recurring commemorations that mark formative events in a nation-state's history or celebrate national heroes play a central role. Often these commemorations take the form of a nation-wide day off work, and their significance is explicated and reinforced by extensive media commentary, thus synchronising, at least for a time, citizens' memories (Zerubavel 2003). More generally, national days invite citizens to remember, re-enact and re-redefine the national past and aim to enhance their emotional attachment to the nation-state. National commemorations are "sites and arenas for the performance of nationhood ... they are moments and spaces where individuals can encounter and perform national identity and belonging" (Roy 2007: 66).

National days are usually staged by state agencies; at the same time they stage the state itself, making it palpable to the citizenry and, potentially, to a wider international audience. The intricate orchestration of the events and the choreography of individual performances demonstrate the state's regulatory power. Also, the use of symbol and ceremony aims to mobilise popular sentiments and strengthen the sense of national belonging. These periodic conflations of nation and state, and the casting of the head of state as 'guardian of the nation', do not only work toward legitimating the state as such, but can also be instrumentalised to bolster the incumbent government.

This does not imply, however, that national days necessarily reconcile controversies regarding the nation's history, current position or future destiny, nor that they in any way homogenise the sometimes competing, sometimes complementary sub-national mnemonic communities (McCrone and McPherson 2009, Elgenius 2005 and 2011). On the contrary, national days often become a forum of debate on the norms and values comprising national identity as well as on state policies, and they also offer opportunities for the articulation of new demands for public recognition. As Michael Geisler (2009) has observed, national days are 'unstable signifiers' that differ from more 'naturalised' elements of 'banal nationalism', such as the omnipresent flags, stamps or country maps shown in the daily news. They occur only once a year and are usually too 'intrusive' to go unnoticed; official explanations of their meaning, however, often invite competing interpretations, and national days thus become the object of "symbolic struggle and capture" (McCrone and McPherson 2009:215).

Eviatar Zerubavel's (2003) survey of national holidays has identified 'historic watersheds', marking key moments in a nation's political history, as a major category of days that nation-states typically commemorate. Indeed, 139 countries of the 191 whose festive calendars Zerubavel has examined celebrate the historic moment at which they became independent as a national 'birthday' and founding moment. Independence days are a peculiar kind of national day, not least because the ceremonies marking the original event, which in many respects provided a model for later anniversary celebrations, were usually carefully crafted from the symbolic and ceremonial 
repertoires of both the departing colonial powers and the local traditions of the newly independent territories. 3

That the official independence anniversaries were, and continue to be, important to the construction of new nation-states in Africa, too, was noted quite early in a perceptive essay by Yves Fauré. Since the state's hold on society was still fragile and conflict-ridden, Fauré (1978:384) argued, the festivals were "a civil cult orchestrated by the state" that aimed at boosting popular support for the incumbent government. However, Fauré's suggestions for further research into African national holidays have remained largely unmet, with a few notable exceptions. Leslie Witz (2003), for instance, has explored the construction of Afrikaner nationalism through the 1952 commemoration of Jan van Riebeeck's arrival in South Africa and the controversies that surrounded these festivities (see also Rassool and Witz 1993). Andrew Apter's (2005) work on the Second World Black and African Festival of Arts and Culture (FESTAC), a great cultural spectacle celebrated in 1977, has shown how the Nigerian government used its recently acquired oil wealth to attempt to create a national culture under the motto 'unity in diversity'. While the FESTAC celebrations aimed at reshaping diverse regional 'traditions' into an "idealized vision of ethnic equality and harmony" (ibid: 9), this image of the Nigerian nation as a federation of diverse but equal regions propelled fierce political competition.

Outside Africa, national holidays and commemorative celebrations have become a rich area of research from which African research can draw some inspiration. Most importantly, scholars of the politics of memory have insisted that 'collective memory' and 'memory-nation' should not be taken for granted and reified; rather, research should focus on 'mnenomic practices' and study cases in which 'memory-makers' fail to make their visions of the past collectively binding (Olick 2003:67). Important here, Charles Turner (2006) notes, is the study of the institutional anchoring and the social organisation of commemorative practices and their contextualisation in a wider ethnography of 'nationhood'. National holidays and commemorations of independence should be understood, therefore, as objects of state policies and as sites of societal contestation.

A number of historical studies that trace the development of a country's festival calendar over a longer period have pointed to the fact that the very introduction and continued celebration of national holidays is often surrounded by political conflict. What Waldstreicher (1997:2) observed for American independence celebrations holds for the history of many national days: they are the outcome of a process marked by both "divisive politics and unifying nationalism at the same time". Sabine Marschall's contribution to this special section offers an instructive example of how drawn-out and complex such negotiations about the introduction of new, and the reconfiguration of existing, national days were in the new South Africa. Similarly, in their study of the history of national days in Madagascar, Helihanta Rajaonarison and Mareike Späth (in this issue) show that the solemn commemoration of suffering (the violent repression of anticolonial resistance on 29 March 1947) and the joyful celebration of victory (the declaration of independence on 29 June 1960) were, and continue to be, not always neatly separated. The fact that Independence Day was celebrated from the first anniversary onwards, while 29 March was not recognised as a public holiday until 1967, was due to contemporary political power constellations - a powerful example that the politics of remembrance is as much about the present as about the past.

\footnotetext{
3 Holland, Williams and Barringer's (2010) volume shows the iconography of these 'freedoms at midnight', and particularly discusses the example of India.
} 
As Lyn Spillman (2003) argues, nations tend to commemorate continuously particularly those historical moments and periods that are relatively vague, abstract and 'multivalent' and that therefore are able to accommodate differing interpretations, even critical counterinterpretations. Drawing on the centennial and bicentennial celebrations of the American Revolution, Spillman shows that these had broad appeal, because "the revolutionary period provided rich grounds for the arguments of commemoration critics," while commemoration planners could "appeal to the 'shared' founding moment in order to transcend salient differences" (2003:185). In contrast, the bicentennial of the arrival of the British in Australia did not have "enough symbolic power to resist critical claims" (ibid.), particularly with regard to the aborigines, to whom this historical event offered no positive associations (Spillman 1997). African independence commemorations clearly belong to the first group of particularly robust national days, despite the fact that in some countries they have been temporarily eclipsed by other national celebrations that commemorated the coming to power of a specific regime, or have been complemented by days that mark additional important moments in the nation's history.4 The cases of Madagascar and the Democratic Republic of Congo (Rajaonarison and Späth; Pype; in this issue), but also those of Zimbabwe and Namibia (Willems; Akuupa and Kornes; in this issue) demonstrate that Independence Day celebrations mobilise public sentiments and feelings of national belonging precisely because they allow for competing visions of the past and rival judgements of actual politics while appealing to a brighter future.

The relationship between state initiative and control of national days on the one hand and civic or popular contributions to and participation in these festivals on the other is a second theme that has been highlighted by studies of national days beyond Africa. Some national ceremonies developed out of regional or local festivals that were only eventually homogenised into one centralised holiday; other festivals have, from the outset, been planned 'from above' by the political centre.5 Elie Podeh's (2011) study of national celebrations in the Arab Middle East shows that national days play a central role, not only in creating and popularising a national founding myth and thus fostering national unity, but also in legitimising incumbent regimes by manifesting power and authority, or even inspiring fear and inculcating subordination. In the case of African independence celebrations, the very historical moment that later came to be commemorated was staged by the departing colonial regimes, together with their African heirs to power. Cannadine's (2010) analysis of the pomp, pageantry and partying during independence declarations in the British Commonwealth shows how India's independence in 1947, carefully crafted to display consensus while concealing tensions and paradoxes, served as a model for the African celebrations. Christine Fricke's (2013) analysis of the 'golden jubilee' of independence in Gabon demonstrates how carefully the national protocol of the celebrations was crafted with an international audience in mind. At the same time, the state organisers drew on popular festive formats such as carnivals, concerts, and cocktail parties to ensure that they mobilised impressive crowds to watch the official programme.

\footnotetext{
${ }^{4}$ For an example from Côte d'Ivoire, where Independence Day is a resilient national celebration but mobilises intense controversy about the history of decolonisation and the making of the new nation-state, see N'Guessan 2013; for a comparative study of the politics of commemoration during the recent Independence Day jubilees in Africa, see Lentz 2013b.

${ }^{5}$ On France and Germany, see Harazeesingh (2004) and Schneider (2005); on the feedback of popular festivals into national celebrations, see Beezley (2008).
} 
Even if orchestrated by political power-holders, however, celebrations could be contested, subversively re-appropriated, or more or less boycotted by the broader population. Furthermore, family or community oriented festivities associated with the official holiday sometimes came to overshadow the official political ritual (Behrenbeck and Nützenadel 2000). Mareike Späth (2013), for instance, has shown how the customary popular celebrations of Madagascar's Independence Day in Madagascar (in the private sphere, the extended family and among neighbours) became a site of upholding the ideal of national unity and faith in a common destiny, in opposition to a government many regarded as illegitimate. Ruptures of the official celebrations through unscheduled interference by citizens also belong in this context, and are illustrated by the example of the Malagasy man inserting a private photograph of his father who had been tortured by the French into an official exhibition (Rajaonarison and Späth, in this issue), or by the Kinshasa case of the unscheduled, offensive ndombolo dances performed during the festive parade, as discussed by Katrien Pype (in this issue).

A third theme emerging from historical research on national days is the contested relationship between regional and ethnic or other group loyalties on the one hand and national identifications on the other. For America, this has been most prominently explored in respect of the legacy of the Civil War, and commemorative fêtes of African-Americans that eventually developed into nation-wide festivals (Blight 2003, Kachun 2003). Ethnic parades and other immigrant festivals, increasingly popular since the later nineteenth century, could be both 'divisive' and 'integrative' with regard to national unity, serving as "forums where claims were made, grievances voiced, social injustice and inequalities or mistreatment exposed, [and] new ideas and strategies tested" (Fabre et al. 2001:13). Thus, national holidays per se do not necessarily reinforce national unity and integration; they can just as well intensify debates and conflicts about what vision of the nation and which future course in respect of the rights of minorities should prevail. For Namibia, for instance, Akuupa and Kornes (in this issue) demonstrate how the official celebrations exemplified the government's recent cultural politics of 'unity in diversity', that is, an attempt to bind regional and ethnic-cultural particularities into an all-encompassing nationhood while saluting cultural differences. Similarly, Marschall (in this issue) discusses the post-1994 South African government's efforts to incorporate pre-existing holidays of regional or ethnic significance into the new nation's festive calendar.

\section{Performing the nation: the aesthetics of national days}

Taking up Kelly Askew's (2002) argument about Tanzania, we propose that nations are not only institutional configurations (as nation-states) and subjective beliefs (Anderson's [1983] 'imagined communities'), but also palpable performative processes. In the performance of the nation, celebrations and commemorations occupy a central place, and performance is thus a key category in research on the role of national days in nation-building and state-making (Roy 2007).

Performance becomes relevant for our theme in two distinct ways. Firstly, performances of various forms, including speeches, marches, public oaths of allegiance, or dance routines and other cultural performances, are central to national-day celebrations. Secondly, a focus on performance emphasises that nationhood "is in no way a stable identity or locus of agency from which various acts proceed; rather, it is an identity tenuously constituted in time an identity instituted through a stylized repetition of acts", as Judith Butler (1988:519) once asserted with reference to the 'performativity' of gender. 
From Askew's work on culture and nationalism in Tanzania we can draw three important suggestions for the analysis of the political aesthetics of national days: firstly, 'performative' necessarily means emergent and contingent; secondly, performance is a process engaging both 'performers' and 'audience', and thirdly, performance does not mirror social reality or merely reflect upon it, it actively creates it (Askew 2002:23).

In the following we will develop these three points further.

The first point suggests that performance is always in process, generated in the moment of production; performance is profoundly sensitive to the politics of moment and space. Nationalism is thus essentially performative, temporary, and impermanent. As indicated above with reference to Butler, nations, like other cultural, political, religious, or regional 'communities', do not exist as such, but are continuously made and remade in interactions between state and non-state actors, rulers and citizen-subjects.

The recent anthropological and historical discussion of nationalism as performative goes far beyond Anderson's (1983) original proposition that the nation existed primarily in the minds of its members (Askew 2002, Handler 1988, Kaur 2005). Anderson's model of the nation as an 'imagined community' generated through print capitalism is limited because it assumes that the political elites make things which others then take for granted, such as a common literacy and language. It fails to explain why the imagination of the national community actually 'works'. It is performance, generated in the moment of production, that allows people to believe that the national imaginary is real. As Raminder Kaur's (2005:4-5) ethnography of performative politics and Hinduism in colonial and postcolonial India, has demonstrated, modes of apprehending the nation ... have been and continue to be, fired by the viscerality of performances - gatherings, marches, campaigns, ceremonies, festivals, processions, and so forth.

Achille Mbembe's (1992) argument about the dramaturgy of the African postcolonial state adds another important point. He demonstrates, with special reference to Cameroon, that performance and ritual play a crucial role in the making and re-making of the relations between rulers and the ruled citizens. Both rulers and citizens contribute, through their shared participation in state-led ceremonies, to what Mbembe calls the 'simulacrum' of an essentially hollow post-colonial state. Katrien Pype takes this argument further in her discussion of the independence festivities as they unfolded in Kinshasa in 2010 and shows that the event involved different layers of motivations, desires and affects, such as pride and shame. ${ }^{6}$ From a different angle, Wendy Willems too refers to the orchestrations of the elite and popular participation in the Zimbabwean case, where, she argues nationalism primarily functions as a mode of control and a way of disciplining Zimbabweans into legal state subjects and ZANU-PF party supporters (Pype, Willems; both in this issue).

Concerning the second point made above, anthropologists of popular culture, such as Askew (2002) and Karin Barber (1997), have convincingly shown that performance is coproduced through the interaction of the 'producers' (performers) and the 'audience', or spectators; audiences have an

\footnotetext{
${ }^{6}$ Pype also draws on more recent work by anthropologists of performance, like Karel Arnaut (2013: 85), which has turned the attention to "elements of heterogeneity in public ritual or ritualized performance" and allows one to understand performance "as an intricate "power play".
} 
active role in constituting performances. Spectators, individually as well as collectively, and related to their distinct social lives and the politics of specific locations, experience reception differently and respond to performances in distinct ways. Pype (in this issue) points out that audiences of national-day celebrations are affectively involved in national-day celebrations. The emotions that are intended to be transmitted to the spectators through specific performances such as marches, speeches, or wreath-laying ceremonies, are not always evoked as intended by the producers. Pype shows that the producers and the audience of national-day celebrations facilitate, obstruct, or prevent the transmission of affects, such as pride in the nation's history. That things sometimes 'go wrong' is thus due to the fact that aesthetic performances can result in different sentiments, shared among and within different sections of the audience, who have their own interpretations of the message intended by the producers.

Thirdly, and resulting from the first two points, we argue that the careful orchestration by political elites notwithstanding, performance and its intersection with nationalism and power are not a matter of representation, but of enactment; that is, the nation only becomes real in the moment of the performance. One may even argue that the performativity of the nation includes the 'fixed' forms in which nationalism manifests, such as monuments, or history textbooks, whose national imaginaries need to be brought to life through performances. Or indeed, whose messages can be confirmed, subverted or altered through performances. Reflecting on the complex connections between performance and power, Johannes Fabian (1990) warned against the fallacious assumption that performance enacted 'a pre-existing script' and insisted that in reality it is 'making, fashioning, creating' (Fabian 1990: 13).

It is thus precisely the inherently unstable and interactive nature of performance that suggests its significance as a category to accommodate the ephemeral and contingent aspects of nation-binding. Performance being open-ended, action rather than recital is unambiguously interrelated with the continuous (re-)negotiation of the nation in general and in national-day celebrations in particular.7

The interactions between producers and audiences of the national-day celebrations can take rather different forms. This is demonstrated by the case studies in this special section. They also show that negotiations, and indeed often contestations, include aesthetics in a dual sense. These two points will be discussed in the remainder of this section.

Where national-day celebrations primarily function as spaces where memories are created, rejected, undermined and recreated, as Rajaonarison and Späth (in this issue) show for Madagascar, commemorations of 'the nation' are subject to vivid historical debates about how to observe these days and how to remember the past. Their Madagascar case study is an example of how the present national days are filled with spectres of the past. In Madagascar the interactions between rulers and ruled, producers and audiences, during national-day ceremonies apparently mostly take the form of verbal debate.

\footnotetext{
7 It makes sense, thus, to complement the conventional concept of 'nation-building', which is more suggestive of construction and building blocks, with the concept of 'nation-binding', that emphasises the fluid, open-ended process of binding and the flexible connections forged through binding.
} 
In other cases, however, national days set the stage for communicative interactions between rulers and subjects not only, and perhaps not primarily, in verbal ways. Willems (in this issue) shows how the citizenry's participation declined dramatically in Zimbabwe's official commemorations of independence; Pype's case study (in this issue) most powerfully demonstrates how embodied aesthetic performance, rather than verbal engagement, by members of the Kinshasa public contributed to the making and re-imagining of the Congolese nation. Pype analyses a disruption of the official national-day celebrations in Kinshasa through the unauthorised entry of citizens into the carefully choreographed setting, and in particular the controversial performance of sexually explicit dances by a group of street children.

The Kinshasa case study thus points out, on the one hand, that, because national days depend on ritual and performance, they always bear the risk of 'failure' or 'slippage', and it is in these potential points of rupture that moments of critique and the articulation of alternative projects become visible (Mookherjee 2011). On the other hand, Pype's exploration also incorporates the approach to aesthetics and politics that Birgit Meyer (2009) has recently developed, which can enrich our analysis of performance and their role in national celebrations. Meyer proposes to replace Anderson's model of 'imagined communities' with 'aesthetic formations', and points to the dual meaning of formation as both 'social entity' and "processes of forming [that] mold particular subjects through shared imaginations that materialize ..., through embodied aesthetic forms" (Meyer 2009: 7; our emphasis).

Many studies have focused on the orchestration of commemorations by political elites and have considered visual, performative and mediated sites of nationalist politics (see, for instance, Kaur 2003 on India), and have developed critical perspectives on the strategic deployment of the visual and performative arts in the construction of the state and nationhood. They have conceptualised aesthetics as 'the beautiful'. The interaction discussed by Pype, however, suggests the significance of a different concept of aesthetics, namely as "our total sensory experience of the world and our sensitive knowledge of it" (Meyer and Verrips 2008: 21). The young dancers who burst into the orchestrated official national-day celebrations in Kinshasa subverted them through the movements of their bodies, which touched upon the senses and "various kinds of affect" (Pype in this issue) of the producers and audience of the performance.

The notion of sensorial and embodied styles (Meyer 2009) with which people apprehend, express and (re)make the world through their bodies and all their senses vision, hearing, touch, smell, and taste - thus can push the research of national days, nation-building and state-making further as it combines aesthetics and affect. It emphasises that performance is essentially embodied symbolic enactment and interaction. A focus on the politics of embodied aesthetics, senses and affect is helpful for understanding the dynamics that become apparent in national celebrations. What is more, the emphasis on aesthetics, the senses and affect allows us to explain why the imagination of the nation as 'community' actually 'works', and why, despite all contestations, citizens and rulers alike believe the imaginary of the 'nation' to be real. Although some may disagree (for instance, Pype in this issue), it can be argued that the rulers' and the citizens' shared sensual and affective participation in national-day celebrations binds them into belonging to a national community, although they may disagree on how to imagine the nation.

The notion of 'collaborative nationalism' introduced by Laura Edmondson (2007) in her study of Tanzanian popular drama is, perhaps, even more applicable in the comparatively uncontested cases 
of postcolonial nation-making in South Africa and Namibia (Marschall; Akuupa and Kornes; both in this issue) than in the 'drama' of Independence Day that demonstrated the divided sentiments in contemporary, postcolonial Kinois society (Pype in this issue). In any case, despite the wide variety of form and content that national-day celebrations can assume, as demonstrated by the case studies in this special section, the celebrations of national days contribute to politico-aesthetic formations of the nation that are at once engendered and contested through sensory, embodied aesthetic performance as well as cultural performances.

\section{The southern African perspective}

In southern Africa, perhaps in a particularly pointed way, the commemorations of national days connect two dimensions.

Firstly, they provide contested templates of imagining the nation, and constitute arenas for the negotiation of other forms of belonging - regional, ethnic - and their intersection with nationhood. Secondly, as we have shown, national-day commemorations and celebrations are about the performance of power.

Drawing on his fieldwork on collective memory and commemorations in Zimbabwe, Richard Werbner (1998) argued that in the southern African context particularly, memories and commemorations of the violent nationalist struggles of the past are crucial in the making of contemporary collective identifications and the subjectivities of persons. Willems (in this issue) demonstrates that in twenty-first century Zimbabwe celebrations of Independence Day continue to be the crucial means through which the ruling party, ZANU-PF, glorifies its role in the liberation struggle, "hereby legitimising its confirmed rule of the country" (in this issue). Drawing on long-term fieldwork in Namibia, Becker (2011) shows that, a decade later, Werbner's proposition still holds true for at least parts of southern Africa, although liberation-war memory, cultural politics and citizenship have recently undergone complex transfigurations in post-colonial Namibia. In that country, as in Zimbabwe, local and national political authorities regularly launch memorialising events through which the postcolonial state explicitly claims continuity with the struggle past; however, over the past decade Namibia has seen a tentative repositioning of liberation war memory. The cultural politics of nationhood have been reinvented in postcolonial Namibia where national identity is no longer to be defined primarily through the common history of the liberation struggle, but through the tolerant accommodation of cultural difference, dubbed 'unity in diversity' (see also Akuupa and Kornes, in this issue). To an extent, official Namibian commemorations, in both physical monuments and ceremonial performances, have been moved away from the 1990 s recitals of a triumphalist, militaristic nationalist master narrative that aimed at homogenising the multi-faceted agencies of Namibians during the liberation war. More recent narratives have begun to recognise the heterogeneous experiences (see also Kössler 2007, Kornes 2010). The former narratives and aesthetics have not gone away; rather they have been altered through the addition of new layers. During the last decade new memorial sites have given visual manifestation to this heterogeneity as well as expressing the particular heritagised Namibian version of the unity-in-diversity discourse (Becker 2011; for South Africa, see Rassool 2000). Similarly, as Akuupa and Kornes's (in this issue) fine-grained ethnography of the Independence Day festivities that took place in Windhoek and two of Namibia's regional capitals shows, the commemorations held in 2010 to celebrate two decades of independence indicated a tentative modification of post-colonial Namibia's prevalent ideational foundations.

\section{http://repository.uwc.ac.za}


Yet, the Zimbabwean and, to a lesser extent, the Namibian case studies in this issue also demonstrate how national-day celebrations continue to spawn the authoritarian condition of postcolonialism. Willems (in this issue) argues that the popular music galas, which she has studied, despite their different performative format, were just slightly more subtle attempts "to discipline Zimbabweans into ZANU-PF's party-nation as compared to the intimidating, official, militarised annual Independence Day ceremony in the National Sports Stadium”. In both Zimbabwe and Namibia, notwithstanding the introduction of new popular forms and a partial shift towards a more inclusive conceptualisation of the nation, mystically venerated historical 'truths' are still presented as fundamental constants of struggle, victory and sacrifice, and rehearsed as formulaic historical narratives of the 'national liberation struggle'. It is these narratives that mediate the former liberation movements', now ruling parties' claims to power in a conflation between nation, state and party, which Willems (in this issue) dubs the 'party-nation'; she thus also indicates the rulers' more recent attempts to incorporate young people literally through 'parties' in the form of the musical galas, which are the focus of her article. ${ }^{8}$

The South African, Malagasy and Congolese case studies (Marschall; Rajaonarison and Späth; Pype; in this issue) demonstrate, however, that the southern African practices of national-day commemorations and celebrations are rather varied. The validity of Werbner's argument is ostensibly limited to certain former settler colonies that gained national independence following a protracted armed liberation struggle. 9

Namibia ostensibly adopted the Zimbabwean model. For instance, both countries' national heroes' acres were built by the same North Korean company; their national commemoration sites embody the same modernist Stalinist realist aesthetics and official national-day celebrations follow similar patterns, as becomes evident by a comparative reading of the contributions by Akuupa and Kornes on Namibia and Willems on Zimbabwe (in this issue; on the memorial sites see Werbner 1998 and Becker 2011).

While it shares the settler-colonial history of Zimbabwe and Namibia, post-apartheid South Africa goes much more cautiously about presenting the nationalist liberation struggle in general, and its armed wing in particular, as the 'new' nation's ultimate foundation myth. South Africans are not treated to military marches past on national days; instead, even though at times controversial, the speeches of national and provincial politicians on occasion of the annual series of (political) national days are complemented with cultural performances. At times 'traditional' dance routines are staged; more conspicuous, however, are the performances of contemporary popular music, especially hip-hop or the South African kwaito. South Africa also differs in that its calendar lacks a central national day, which would be comparable to the commonly celebrated Independence Day of African post-colonies. As Marschall's (in this issue) discussion of the rearrangement of the South African national festive calendar after 1994 points out, 'Freedom Day', the public holiday introduced in memory of the first inclusive democratic elections, was only a belated addition in the complex negotiation of the post-apartheid holiday policy. Even though there is good reason to be wary of claims to South African exceptionalism, in this instance a significant

\footnotetext{
${ }^{8}$ For a sophisticated analysis of the party-state-nation conflation in postcolonial Namibia, see Du Pisani (2010).

${ }^{9}$ Armed combat may in reality not have been the decisive force in the eventual defeat of the colonial regimes in Zimbabwe and Namibia; however, in both countries the liberation-movements-turned-ruling-parties developed master narratives of national liberation that revolve around the central ploy that the former liberation movements brought us freedom "through the barrel of the gun" (Becker 2011; Werbner 1998).
} 
distinction is apparent: the country's new national days were designed against the foil of a set of pre-existing national (public) holidays intended to transmit previous imaginations of the nation, especially in its exclusive Afrikaner and, in the later apartheid years, exclusive White South African versions (see also Witz 2003; Rassool and Witz 1993; Louw 2009). In the negotiated settlement that gave rise to the 'new' South Africa, these established national days were retained, though renamed and reinterpreted. Days that had marked significant historical events during the decades of the liberation struggle were similarly reinvented in the context of the efforts in the 1990s of 'negotiating the past' (Nuttall and Coetzee 1998) with the aim to enhance affective as well as political nation-binding.

Most of southern Africa was incorporated into the orbit of South African empire for more than a century. Colonial, segregationist, and apartheid South Africa cast a net of economic and political ties over the subcontinent that ranged from the histories of forced migration, direct colonial rule in the instance of Namibia, and transnational labour migration through to the violent raids and border wars of the late apartheid period, thus constituting a politico-historical region of Southern Africa, with a capital 'S'.

The political motivations of rulers and citizens, as much as the affects imagined and felt by choreographers and audiences, are ostensibly different in the former French and Belgian colonies of Madagascar and the Congo, whose contested national-day festivities are analysed in the contributions by Rajaonarison and Späth, and Pype respectively. In Madagascar the debates about the commemoration and celebration of two different national days are, to a certain extent, still linked to the memory of colonial history and the attainment of independence. This includes both remembrance and its flipside, forgetting, in the island nation's memoryscape, as Jennifer Cole (2001) has pointed out. The contestations in the Democratic Republic of Congo, and particularly in its capital Kinshasa, on the other hand, appear to be entirely a matter of the postcolony. ${ }^{10}$ As Pype (in this issue), following Mbembe (1992) and Karlström (2003) shows, ceremonies such as those staged on the fiftieth anniversary of the attainment of Congolese independence have become the privileged 'language' through which the rulers speak. At the same time, they have become a stage for communicative interaction between the rulers and the ruled - a stage on which, Pype concludes, the citizens of the capital showed the country's political elite that in their eyes the country's rulers did not belong to the national community as imagined and experienced by the Kinois.

It appears, then, that there is no single southern African perspective on national days. The triumphalist, militaristic, modernist aesthetics of the post-liberation regimes, rather, captured the spirit of particular times and spaces in Southern Africa with a capital 'S'. In the geographical region (with a lower case 's') we find a broader variety of national commemorations and celebrations orchestrated by the countries' political elites, and supported or contested in different forms by citizens. These range from a comparatively enthusiastic participation in official festivities (as reported by Akuupa and Kornes for Namibia) to different forms of withdrawal and obliviousness (discussed by all other authors), verbal discursive debates about the historical

\footnotetext{
${ }^{10}$ However, as Vanessa Petzold $(2011 ; 2013)$, who carried out fieldwork in the scientific committee that helped prepare the cinquantenaire ceremonies shows, history did play an important role in the organisers' discussions on how to celebrate fifty years of independence. The very president of the scientific committee was a renowned historian who published, just in time for the jubilee, a comprehensive history of the Congo; the invitation of the Belgian king to attend the major ceremonies provoked intensive debates on the role of colonialism in national history; and several large-scale 'national conferences' in the run-up to the celebrations focused on historical themes.
} 
meaning of national days (discussed especially for the Malagasy case), and the spectacular aesthetic and affective anti-performance in Kinshasa. 


\section{References}

Anderson, Benedict. 1983: Imagined Communities: Reflections on the Origin and Spread of Nations. London: Verso.

Apter, Andrew. 2005. The Pan-African Nation: Oil and the Spectacle of Culture in Nigeria. Chicago: Chicago University Press.

Arnaut, Karel. 2013. 'Making Space for Performativity: Publics, Powers, and Places in a MultiRegister Town Festival (Bondoukou, Cote d'Ivoire),' in Devising Order: Socio-Religious Models, Rituals, and the Performativity of Practice. Edited by Bruno Boute and Thomas Smâberg, pp 81-102. Leiden and Boston: Brill Publishers.

Askew, Kelly M. 2002. Performing the Nation: Swahili Music and Cultural Politics in Tanzania. Chicago: University of Chicago Press.

Barber, Karin. 1997. Notes on Audiences in Africa. Africa: Journal of the International African Institute 67 (3): 347-362.

Becker, Heike. 2011. Commemorating heroes in Windhoek and Eenhana: memory, culture and nationalism in Namibia, 1990- 2010. Africa. Journal of the International African Institute 81(4): 519-43.

Beezley, William H. 2008. Mexican National Identity: Memory, Innuendo, and Popular Culture. Tucson: University of Arizona Press.

Behrenbeck, Sabine and Alexander Nützenadel. Eds. 2000. Inszenierungen des Nationalstaats. Politische Feiern in Italien und Deutschland seit 1860/71. Cologne: SHVerlag.

Blight, David W. 2003. Race and Reunion: The Civil War in American Memory. Cambridge, Mass.: Belknap Press of Harvard University Press.

Butler, Judith. 1988. Performative Acts and Gender Constitution: An Essay in Phenomenology and Feminist Theory. Theatre Journal 40(4): 519-531.

Cannadine, David. 2010. 'Introduction: Independence Day ceremonials in historical perspective,' in The Iconography of Independence: 'Freedoms at Midnight'. Edited by R. Holland, S. Williams and T. Barringer, pp 117. New York: Routledge.

Cole, Jennifer.2001. Forget Colonialism?: Sacrifice and the Art of Memory in Madagascar. Berkeley: University of California Press.

Du Pisani, André. 2010. 'The discursive limits of SWAPO's dominant discourses on anti-colonial nationalism in postcolonial Namibia - a first exploration,' in The Long Aftermath of War: reconciliation and transition in Namibia. Edited by André du Pisani, Reinhart Kössler and William A. Lindeke, pp1-40. Freiburg i. Br.: Arnold-Bergstraesser- Institut.

Edmondson, Laura. 2007. Performance and Politics in Tanzania. The Nation on Stage. Bloomington: Indiana University Press. Elgenius, Gabriella. 2005. 'National days and nation-building,' in Statehood Before and Beyond Ethnicity: Minor States in Northern and Eastern Europe, 1600-200o. Edited by L. Eriksonas and L. Müller, pp 36384. Brüssel: Peter Lang.

Elgenius, Gabriella. 2011. Symbols of Nations and Nationalism: Celebrating Nationhood. London: Palgrave Macmillan.

Fabian, Johannes. 1990. Power and Performance: Ethnographic Explorations through Proverbial Wisdom and Theater in Shaba, Zaire. Madison, WI: University of Wisconsin Press.

Fabre, Geneviève, Jürgen Heideking and Kai Dreisbach. Eds. 2001. Celebrating Ethnicity and Nation: American Festive Culture from the Revolution to the Early Twentieth Century. New York: Berghahn.

Fauré, Yves.-A. 1978. Célébrations officielles et pouvoirs africains. Symbolique et construction de l'État. Canadian Journal of African Studies 12 (3): 383404. 
Fox, Jon E.; Cynthia Miller-Idriss. 2008. Everyday nationhood. Ethnicities 8 (4): 53676.

Fricke, Christine. 2013. Protocol, politics, and popular culture: the independence jubilee in Gabon. Nations and Nationalism 19 (2): 23856.

Geisler, Michael E. 2005. 'Introduction: what are national symbols and what do they do to us?,' in National Symbols, Fractures Identities: Contesting the National Narrative. Edited by M. E. Geisler, pp 1324. Hanover and London: University Press of New England.

Geisler, Michael E. 2009. 'The calendar conundrum: national days as unstable signifiers,' in National Days: Constructing and Mobilising National Identity. Edited by D. McCrone and G. McPherson, pp 1025. London: Palgrave Macmillan.

Gellner, Ernest. 1983. Nations and Nationalism. Ithaca, NY: Cornell University Press.

Gillis, John R. 1994. 'Memory and and identity: the history of a relationship,' in Commemorations: The Politics of National Identity. Edited by J. R. Gillis, pp 324. Princeton: Princeton University Press.

Handler, Richard. 1988. Nationalism and the Politics of Culture in Quebec. Madison, WI: University of Wisconsin Press.

Holland, Robert, Susan Williams and Terry Barringer. Eds. 2010. The Iconography of Independence: 'Freedoms at Midnight'. New York: Routledge.

Kachun, Mitch. 2003. Festivals of Freedom: Memory and Meaning in African American Emancipation Celebrations, 1808-1915. Amherst: University of Massachussetts Press.

Karlström, Mikael. 2003. On the Aesthetics and Dialogics of Power in the Postcolony. Africa 73 (1): 57-77.

Kaur, Raminder. 2005. Performative Politics and the Cultures of Hinduism: Public Uses of Religion in Western India. London: Anthem Press.

Kössler, Reinhart. 2007. Facing a fragmented past: memory, culture and politics in Namibia. Journal of Southern African Studies 33 (2): 361-82.

Kornes, Godwin. 2010. Whose blood waters whose freedom?

Gegenerinnerungen in der namibischen Interniertenfrage. Working Papers of the Department of Anthropology and African Studies, Mainz University, 122 <www.ifeas.uni-mainz.de/ workingpapers/AP122. Pdf > Accessed: 20 July 2012 .

Lentz, Carola, 2013a. Celebrating independence jubilees and the millennium: national days in Africa. Nations and Nationalism 19 (2): 20816.

Lentz, Carola, 2013b. The 2010 independence jubilees: the politics and aesthetics of national commemoration in Africa. Nations and Nationalism 19 (2): 21737.

Lentz, Carola and Godwin Kornes (eds.) 2011: Staatsinszenierung, Erinnerungsmarathon und Volksfest. Afrika feiert 50 Jahre Unabhängigkeit. Frankfurt/M.: Brandes \& Apsel.

Louw, Eric P. 2009. 'Afrikaner's nationalism's holy day: from commemoration through hegemony to delegitimation' in National Days: Constructing and Mobilising National Identity edited by D. McCrone and G. McPherson, pp 89104. London: Palgrave Macmillan.

Mbembe, Achille. 1992. Provisional Notes on the Postcolony. Africa 62 (1): 3-37.

McCrone, David and Gayle McPherson. 2009. 'Marking time: the significance of national days' in National Days: Constructing and Mobilising National Identity edited by David McCrone and Gayle McPherson, pp 21221. London: Palgrave Macmillan.

Meyer, Birgit. 2009. 'Introduction: From Imagined Communities to Aesthetic Formations: Religious Mediations, Sensational Forms, and Styles of Binding,' in Aesthetic Formations. Media, Religion, and the Senses. Edited by Birgit Meyer, pp 1-30. New York: Palgrave/MacMillan. 
Meyer, Birgit; Jojada Verrips. 2008. 'Aesthetics', in Key Words in Religion, Media and Culture, edited by David Morgan, pp 20-30. New York: Routledge.

Mookherjee, Nayanika. 2011. 'The aesthetics of nations: anthropological and historical approaches'. Journal of the Royal Anthropological Institute N.S. (special issue): S1S20.

N'Guessan, Konstanze. 2013. 'Independence is not given, it is taken': The Ivorian cinquantenaire and competing histories of independence. Nations and Nationalism 19 (2): 27595.

Nuttall, Sarah; Carli Coetzee. Eds.1998. Negotiating the Past: The making of memory in South Africa. Cape Town: Oxford University Press.

Olick, Jeffrey K. 2003. States of Memory: Continuities, Conflicts and Transformations in National Retrospection. Durham: Duke University Press.

Petzold, Vanessa. 2011. 'Der Traum von einer besseren Zukunft.

Das Cinquantenaire in der Demokratischen Republik Kongo' in Staatsinszenierung, Erinnerungsmarathon und Volksfest. Afrika feiert 50 Jahre Unabhängigkeit edited by Carola Lentz and Godwin Kornes, pp 93109. Frankfurt/M.: Brandes \& Apsel.

Petzold, Vanessa. 2013. 'Building a nation is also dreaming together': Das Cinquantenaire der Demokratischen Republik Kongo. Unpublished MA thesis, Department of Anthropology and African Studies, Mainz University.

Podeh, Elie. 2011. The Politics of National Celebrations in the Arab Middle East. Cambridge: Cambridge University Press.

Rassool, Ciraj. 2000. The rise of heritage and reconstitution of history in South Africa. Kronos. Journal of Cape History 26: 121.

Rassool, Ciraj and Leslie Witz. 1993. The 1952 Jan Van Riebeeck tercentenary festival: constructing and contesting public national history in South Africa. Journal of African History 34 (3): 44768.

Roy, Srirupa. 2007. Beyond Belief: India and the Politics of Postcolonial Nationalism. Durham: Duke University Press.

Schneider, Ute. 1995. Politische Festkultur in 19. Jahrhundert. Die Rheinprovinz von der französischen Zeit bis zum Ende des Ersten Weltkriegs (1806-1918). Essen: Klartext Verlag.

Späth, Mareike. 2013. Madagascar's independence jubilee: a nation's holiday in times of crisis. Nations and Nationalism 19 (2): 25775.

Spillman, Lyn. 1997. Nation and Commemoration: Creating National Identities in the United States and Australia. Cambridge: Cambridge University Press.

Spillman, Lyn. 2003. 'When do collective memories last? Founding moments in the United States and Australia' in States of Memory: Continuities, Conflicts and Transformations in National Retrospection. Edited by J. Olick, pp 16192. Durham: Duke University Press, 16192.

Turner, Charles. 2006: 'Nation and commemoration' in The Sage Handbook of Nations and Nationalism. Edited by G. Delanty and K. Kumar, pp 20513. London: Sage.

Waldstreicher, David. 1997. In the Midst of Perpetual Fetes: The Making of American Nationalism, 17761820. Chapel Hill: University of North Carolina Press.

Werbner, Richard. 1998. 'Smoke from the barrel if a gun: postwars of the dead, memory and reinscription in Zimbabwe' in Memory and the Postcolony: African Anthropology and the Critique of Power. Edited by R. Werbner, pp 71102. London: Zed Books.

Williams, Sue, Robert Holland and Terry A. Barringer. 2010. 'Preface: the Midnight Hour' in The Iconography of Independence:

'Freedoms at Midnight'. Edited by R. Holland, S. Williams and T. Barringer, pp ixxix. London: Routledge. 
Witz, Leslie. 2003. Apartheid's Festival: Contesting South Africa's National Pasts. Bloomington: Indiana University Press.

Zerubavel, Eviatar. 2003. 'Calendars and history: a comparative study of the social organization of national memory,' in States of Memory: Continuities, Conflicts and Transformations in National Retrospection. Edited by J. Olick, pp 31537. Durham: Duke University Press. 